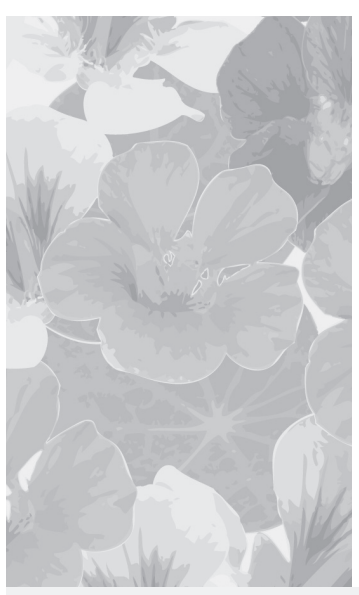

\title{
Edukacja zdrowotna i promocja zdrowia w gabinecie kosmetologicznym
}

\author{
Health education and health promotion in beauty salons
}

Danuta Plichta, Radosław Śpiewak

Zakład Dermatologii Doświadczalnej i Kosmetologii, Wydział Farmaceutyczny Uniwersytet Jagielloński Collegium Medicum, Kraków

Estetol Med Kosmetol 2012; 2(2): 44-49

DOI: http://dx.doi.org/10.14320/EMK.2012.009

\section{Streszczenie}

Współczesny gabinet kosmetologiczny to nie tylko miejsce upiększania i pielęgnacji ciała ludzkiego, ale także obszar realizacji edukacji zdrowotnej i kształtowania zachowań prozdrowotnych. Kosmetolog ze względu na swoje wyksztatcenie doskonale nadaje się do roli promotora zdrowia, może stać się także realizatorem programów edukacyjnych. Celem niniejszego artykutu był przegląd dostępnej literatury na temat programów edukacji zdrowotnej prowadzonych w gabinecie kosmetologicznym. Materiat i metody: Dokonano przeglądu oryginalnych prac badawczych opisujących działania z zakresu edukacji zdrowotnej na terenie gabinetu kosmetologicznego. Przeszukano bazy bibliograficzne PubMed, Embase, Scopus, Web of Science, Google Scholar, a ponadto dokonano ręcznego przeglądu dwóch polskich czasopism naukowych poświęconych kosmetologii (Polish Journal of Cosmetology, od 1998 do 2011 roku) oraz zdrowiu publicznemu i promocji zdrowia (Zdrowie Publiczne, od 2001 do 2011 roku). Z analizy wyłączono publikacje dotyczące edukacji zdrowotnej realizowanej w salonie kosmetycznym przez nie-kosmetologów (fryzjerów lub stylistów). Wyniki: Zidentyfikowano 16 publikacji na temat roli kosmetologa jako edukatora zdrowotnego oraz promotora zdrowia. Opracowano tabelaryczne zestawienie oryginalnych prac opisujących programy zdrowotne w gabinetach kosmetologicznych wraz z omówieniem efektów realizowanych programów. Wnioski: Kosmetolog w petni kwalifikuje się do roli edukatora zdrowotnego. Gabinety kosmetologiczne wydają się idealnym miejscem szerzenia informacji zdrowotnych. Dotychczasowe doświadczenia pokazują, że realizacja programów promocji zdrowia na terenie gabinetu kosmetologicznego przynosi oczekiwane efekty.

Stowa kluczowe: edukacja zdrowotna, promocja zdrowia, kosmetolog, gabinet kosmetologiczny, salon kosmetyczny

\section{Abstract}

A modern beauty salon is not only a place for beauty care and body treatment, but also an area of active health education and promotion of healthy behaviours. Thanks to their educational backgrounds, cosmetologists may become health promoters and carry out educational programmes in beauty salons. Aim: A review of available literature on health education programmes carried out in beauty salons. Material and methods: A literature search of original papers describing health education programmes carried out in beauty salons. The following bibliographic databases were searched: Pubmed, Embase, Scopus, Web of Science and Google Scholar Moreover, two Polish scientific journals devoted to cosmetology - Polish Journal of Cosmetology (1998-2011) and health promotion - Zdrowie Publiczne (2001-2011) were hand-searched. Publications concerning health education in beauty salons carried out by noncosmetologists (hairdressers and stylists) were excluded from the present analyses. Results: Sixteen articles dedicated to the role of the cosmetologist as a health educator and health promoter were identified and included into this review. Results of the search were compiled in a table presenting health programmes in beauty salons, together with their results. Conclusions: The cosmetologist is fully eligible for the role of health educator. Beauty salons seem to be a perfect place for disseminating health education. Past experience confirms that implementation of health promotion programmes in beauty salons delivers the expected results.

Keywords: health education, health promotion, cosmetologist, beauty salon, beauty shop

Copyright @ 2012 the Authors (text) and Radosław Śpiewak (layout \& journal compilation). All rights reserved.

\section{Wstęp}

Współczesny gabinet kosmetologiczny to nie tylko miejsce pielęgnacji i upiększania ciała, ale także obszar budowania świadomości zdrowotnej i kształtowania zachowań prozdrowotnych u klientów korzystających z usług kosmetycznych. Promocję zdrowia definiuje się jako ,proces umożliwiający ludziom kontrolę nad własnym zdrowiem oraz jego poprawę poprzez podejmowanie wyborów i decyzji sprzyjających zdrowiu, kształtowanie potrzeb i kompetencji do rozwiązywania problemów zdrowotnych oraz zwiększanie potencjału zdrowia" [1]. Głównym narzędziem realizacji promocji zdrowia jest edukacja zdrowotna. Według Światowej
Organizacji Zdrowia (WHO), zadaniem edukacji zdrowotnej jest dostarczenie jednostkom oraz wspólnocie wiedzy i umiejętności niezbędnych do przyjęcia zachowań korzystnych dla zdrowia [2]. Kosmetolog posiada wykształcenie z zakresu anatomii, fizjologii, dermatologii, a także chorób cywilizacyjnych (tab. 1), dlatego wydaje się doskonałym kandydatem do roli promotora zdrowia oraz do prowadzenia edukacji zdrowotnej. Regularne wizyty klientek w salonie kosmetycznym, korzystanie z usług jednego kosmetologa oraz postrzeganie salonu jako przyjaznego miejsca sprzyjają nawiązaniu relacji zaufania i więzi, które zachęcają klientki do dzielenia się swoimi problemami zdrowotnymi [3]. Dobrze wykształcony i świadomy zagrożeń zdrowot- 
nych kosmetolog nierzadko jako pierwszy może wykryć nieprawidłowości w wyglądzie lub funkcjonowaniu organizmu [4]. Korzystając ze swojej wiedzy, kosmetolog może zatem skutecznie zachęcić klientkę do stosownych działań prozdrowotnych lub, gdy to niezbędne, skierować do właściwego specjalisty [5].

Tabela 1. Standardy ksztatcenia na kierunku Kosmetologia (wybór) [6]

\begin{tabular}{|c|c|c|}
\hline \multicolumn{3}{|c|}{ Studia pierwszego stopnia } \\
\hline Nazwa przedmiotu & $\begin{array}{l}\text { Liczba } \\
\text { godzin }\end{array}$ & Efekty kształcenia - umiejętności i kompetencje: \\
\hline Anatomia & 30 & $\begin{array}{l}\text { „Rozpoznawanie zasadniczych struktur ludzkiego } \\
\text { ciała oraz ich lokalizacji; rozumienia zależności } \\
\text { między budową a czynnością narządu.” }\end{array}$ \\
\hline Histologia & 30 & $\begin{array}{l}\text { „Posługiwanie się wiedzą z zakresu prawidłowej } \\
\text { budowy histologicznej tkanek i narządów; } \\
\text { rozpoznawania tkanek i narządów w preparatach } \\
\text { mikroskopowych.” }\end{array}$ \\
\hline $\begin{array}{l}\text { Fizjologia i } \\
\text { patofizjologia }\end{array}$ & 60 & $\begin{array}{l}\text { „Rozumienie i opis mechanizmów funkcjonowania } \\
\text { organizmu ludzkiego; rozumienia poszczególnych } \\
\text { funkcji organizmu ludzkiego jako powiązanych } \\
\text { elementów zintegrowanej całości; rozumienia } \\
\text { i opisu mechanizmów rozwoju zaburzeń } \\
\text { czynnościowych; oceny wpływu czynników } \\
\text { patogennych na stan czynnościowy organizmu.” }\end{array}$ \\
\hline Higiena & 30 & $\begin{array}{l}\text { „Rozumienie i ocena jakości zdrowotnej w relacji } \\
\text { do stanu środowiska; propagowania i prowadzenia } \\
\text { działań profilaktycznych (...)” }\end{array}$ \\
\hline Dermatologia & 90 & $\begin{array}{l}\text { „Rozpoznawanie chorobowych zmian skóry; } \\
\text { odpowiedniego postępowania zaleconego przez } \\
\text { lekarza w przypadku chorobowych zmian skóry } \\
\text { i paznokci.” }\end{array}$ \\
\hline \multicolumn{3}{|c|}{ Studia drugiego stopnia } \\
\hline Alergologia & 30 & $\begin{array}{l}\text { „Rozpoznawanie zmian o podłożu alergicznym; } \\
\text { dobór metod i testów do oceny reakcji alergicznych." }\end{array}$ \\
\hline $\begin{array}{l}\text { Chirurgia plastyczna, } \\
\text { pourazowa } \\
\text { i estetyczna }\end{array}$ & 45 & $\begin{array}{l}\text { „Stosowanie kamuflażu defektów skóry; } \\
\text { posługiwanie się wiedzą o chirurgicznych metodach } \\
\text { usuwania defektów”. }\end{array}$ \\
\hline Endokrynologia & 30 & $\begin{array}{l}\text { „Wykorzystywanie wiedzy na temat chorób } \\
\text { endokrynologicznych; ocena wpływu chorób } \\
\text { endokrynologicznych na zmiany w obrębie skóry } \\
\text { i jej przydatków.” }\end{array}$ \\
\hline Onkologia skóry & 30 & $\begin{array}{l}\text { „Wykorzystywanie wiedzy na temat nowotworów } \\
\text { skóry oraz nowotworów ogólnoustrojowych } \\
\text { z manifestacją skórną; przeprowadzanie wywiadu } \\
\text { dermatologiczno-kosmetycznego; rozpoznawania } \\
\text { zmian skórnych w stanach przednowotworowych.” }\end{array}$ \\
\hline Rehabilitacja & 30 & $\begin{array}{l}\text { „(...) podejmowanie działań w zakresie profilaktyki } \\
\text { zdrowia i łagodzenia dolegliwości u osób otyłych } \\
\text { i w podeszłym wieku.” }\end{array}$ \\
\hline
\end{tabular}

\section{Cel}

Celem niniejszej pracy był przegląd dostępnej literatury naukowej poświęconej edukacji zdrowotnej w gabinecie kosmetologicznym. Cele szczegółowe obejmowały analizę przedstawionych w piśmiennictwie programów edukacji zdrowotnej prowadzonych w gabinecie kosmetologicznym, określenie roli kosmetologów i salonów kosmetologicznych w działaniach prozdrowotnych, a także analizę dostępnych informacji na temat skuteczności programów promocji zdrowia prowadzonych w salonach kosmetycznych.

\section{Materiat i metody}

Przeszukano bazy bibliograficzne PubMed, Embase,
Scopus, Web of Science, Google Scholar używając kombinacji następujących słów kluczowych: 'health education', 'health promotion', 'beautician', 'cosmetologist', 'beauty salon', 'beauty parlour', 'beauty shop', 'health'. Dokonano także ręcznego przeglądu dwóch polskich czasopism naukowych poświęconych kosmetologii (Polish Journal of Cosmetology, od 1998 do 2011 roku) oraz zdrowiu publicznemu i promocji zdrowia (Zdrowie Publiczne, od 2001 do 2011 roku). Do niniejszego przeglądu włączono publikacje oryginalne opisujące działania z zakresu edukacji zdrowotnej prowadzonej przez kosmetologów, a także programy promocji zdrowia prowadzone w salonach kosmetologicznych. $Z$ analizy wykluczono publikacje dotyczące edukacji zdrowotnej prowadzonej przez fryzjerów lub stylistów [7-9].

\section{Wyniki}

Zidentyfikowano 16 publikacji, które spełniły podane wyżej kryteria włączenia. Na ich podstawie można było wyodrębnić trzy sposoby realizacji edukacji zdrowotnej w salonie kosmetologicznym:

1. kosmetolodzy jako samodzielni edukatorzy zdrowotni działający na podstawie wiedzy i umiejętności nabytych w trakcie kształcenia do zawodu,

2. kosmetolodzy jako celowo przeszkoleni promotorzy zdrowia realizujący programy edukacji zdrowotnej opracowane przez różne stowarzyszenia i organizacje,

3. salony kosmetologiczne jako miejsce edukacji zdrowotnej realizowanej przez niebędących kosmetologami wolontariuszy organizacji promujących zdrowie, ze względu na możliwość dotarcia do szerokiego grona odbiorców.

Kosmetolog jako wykształcony edukator zdrowotny. Kosmetolog ze względu na swoje wykształcenie wydaje się być odpowiednią osobą do edukowania klientów w zakresie profilaktyki i prewencji chorób, a także promocji zdrowia. Makowska i Frączek podkreślają, że posiadane kompetencje uzasadniają włączenie kosmetologów w proces rozwiązywania problemów zdrowotnych ludzi i uznanie ich za liderów promocji zdrowia [10]. Antoszewski i wsp. [11] dodają, że przyszłe specjalistki w dziedzinie kosmetologii są świadome zagrożeń zdrowotnych związanych z nowotworami skóry i wykazali w swoich badaniach, że wszystkie studentki podczas wykonywania pracy w gabinecie kosmetologicznym obserwują zmiany skórne na ciele klienta, informują o zauważonych zmianach i sygnalizują konieczność ich przebadania przez specjalistę. Według Kuźmicz i wsp. [4] kosmetolog to również jedna z pierwszych osób, które mogą wykryć zmiany patologiczne w piersi kobiecej. Podczas wykonywania zabiegów pielęgnacyjnych w obrębie piersi, kosmetolog ma szansę wyczuć zmiany w ich strukturze lub zauważyć niepokojące 
zmiany w wyglądzie. Zabiegi w obrębie piersi dają dodatkowo możliwość przełamania tabu i podjęcia dialogu na temat nowotworu sutka. Autorki podkreślają, że obowiązkiem kosmetologa jest niezwłoczne skierowanie klientki z podejrzanymi objawami do lekarza specjalisty w celu wykluczenia lub potwierdzenia choroby. Rola kosmetologa w zakresie prewencji chorób skóry została opisana w pracy Dany i Makowiec-Dąbrowskiej [12], według których kosmetolog jako osoba zawodowo zajmująca się skórą ludzką powinien przyczyniać się do podwyższania świadomości klientów na temat czynników ryzyka nowotworów złośliwych skóry, promować pozytywny obraz nieopalonej skóry i zachęcać klientów do rezygnacji z kąpieli słonecznych oraz solarium.

Rola edukatora zdrowotnego w opinii kosmetologów i klientów. Obecność edukacji zdrowotnej W gabinecie kosmetologicznym spotyka się z aprobatą zarówno ze strony kosmetologów, jak i klientek korzystających z ich usług. Z opublikowanych badań wynika, że zdecydowana większość kosmetologów rozmawia z klientami na tematy dotyczące zdrowia. Najczęściej są to kwestie zdrowego odżywiania, diety i kontroli wagi, wysokiego ciśnienia krwi, aktywności fizycznej, stresu i mammografii [13], a także tematy związane z ciążą, macierzyństwem i bólem pleców [14]. Preferowanym przez kosmetologów źródłem informacji o zdrowiu są broszury i filmy edukacyjne, zaś najlepszą w ich opinii metodą dzielenia się tymi informacjami zdrowotnymi z klientkami jest wręczanie ulotek oraz rozmowa. Salon kosmetyczny to w opinii cytowanych autorów ,miejsce idealne” do promowania zdrowia. Przeciętny kosmetolog przyjmuje 47 klientów tygodniowo, a jedna wizyta zajmuje średnio 30-60 minut, niekiedy nawet kilka godzin. Sytuacja ta bardzo sprzyja edukacji zdrowotnej [13]. Solomon i wsp. określają kosmetologa mianem „naturalnego pomocnika" (ang. natural helper) w dziedzinie zdrowia [14]. Także Lieberman i Harris [15] wskazują, że klienci często podejmują z kosmetologami rozmowy na tematy zdrowotne. Kosmetolodzy są chętni podejmować rolę promotora zdrowia i, jak podkreślają autorzy, często doradzają klientom wizytę u specjalisty lub namawiają do zaprzestania palenia. Co więcej, nastolatki w wieku 16-18 r. ż. są bardziej skłonne pytać kosmetologa niż swoich rodziców o informacje związane ze sferą seksualną [15].

Kosmetolog jako celowo przeszkolony edukator zdrowotny. Tabela 2 przedstawia zrealizowane $z$ udziałem kosmetologów programy zdrowotne poświęcone takim problemom, jak prewencja raka piersi i innych nowotworów lub udaru poprzez dostarczenie informacji zdrowotnych (edukacja) i zachętę do poprawy stylu życia (promocja zdrowia). Jak dotąd, wszystkie opisane w literaturze programy edukacyjne realizowane przez przeszkolonych kosmetologów skierowane były do klientek rasy czarnej (Afroamerykanki) jako populacji o największej chorobowości i umieralności na nowotwory piersi, udar, cukrzycę, a zarazem o niskim poziomie zachowań prozdrowotnych. Oprócz interwencji w postaci edukacji i promocji zdrowia kosmetolodzy uczestniczyli również w badaniach mających na celu poznanie poziomu świadomości zdrowotnej wśród Afroamerykanek [16-19]. Collins i wsp. uzasadniają wybór kobiet, jako grupy docelowej programów edukacyjnych, ich rolą społeczną związaną z opieką nad dziećmi i innymi krewnymi, co czyni je rodzinnymi autorytetami w dziedzinie zdrowia [20]. W ramach opublikowanych badań, kosmetolodzy po wcześniejszym przeszkoleniu przez prozdrowotne organizacje i stowarzyszenia edukowali klientki podczas wizyt w salonie. Ich zadaniem była między innymi nauka samobadania piersi, motywowanie klientek do aktywności fizycznej oraz spożywania warzyw i owoców oraz picia wody. Kosmetolodzy posługiwali się przy tym broszurami informacyjnymi oraz plakatami.

Efekty prowadzonych programów edukacji zdrowotnej. Najczęstszą metodą oceny efektów prowadzonych programów były ankiety rozprowadzane wśród klientek przed rozpoczęciem programu edukacyjnego oraz po jego zakończeniu. Przeciętny czas trwania programu wynosił 6-7 tygodni. W programie prewencji raka piersi, klientki po uzyskaniu informacji o podwyższonym ryzyku zachorowania na nowotwór piersi były bardziej skłonne do samobadania piersi oraz wykonania mammografii [16]. Program prewencji raka piersi wśród czarnoskórych Amerykanek z udziałem kosmetologa opisuje także Forte, jednak bez podania efektów programu [21]. Zachęcające wyniki programu prewencji nowotworów poprzez zmianę stylu życia opisali natomiast Linnan i wsp. [22]: ponad połowa klientek uczestniczących $\mathrm{w}$ ich badaniu dokonała prozdrowotnych zmian w swoich zachowaniach, większość skorzystała z infolinii telefonicznej na temat nowotworów, przestrzegała spożycia warzyw i owoców co najmniej 5 razy dziennie, a także wykonywała codziennie 30-minutowe ćwiczenia fizyczne. Podobnie też w programie Johnsona i wsp. uzyskano zwiększenie konsumpcji owoców i warzyw do przynajmniej 5 razy dziennie, jednak w odniesieniu do aktywności fizycznej i spożycia wody poprawa w tym samym programie okazała się nieistotna statystycznie, co autorzy tłumaczą zbyt dużą ilością informacji przekazywanych w jednym czasie [23]. Kleindorfer i wsp. w swoim programie uzyskali poprawę poziomu wiedzy o objawach udaru mózgu, jednak nie osiągnęli tego w zakresie wiedzy na temat czynników ryzyka tej choroby [24].

Gabinet kosmetologiczny jako miejsce realizacji promocji zdrowia. Edukacja zdrowotna w salonie kosmetologicznym wydaje się doskonałym rozwiązaniem nie tylko ze względu na wykształcenie i przygo- 
Tabela 2. Przegląd prac oryginalnych przedstawiających programy edukacji zdrowotnej w salonach kosmetologicznych

\begin{tabular}{|c|c|c|c|c|c|c|c|}
\hline Publikacja & $\begin{array}{l}\text { Opis } \\
\text { programu }\end{array}$ & Grupa badana & $\begin{array}{l}\text { Treść edukacji } \\
\text { zdrowotnej }\end{array}$ & $\begin{array}{c}\text { Sposób prowadzenia edukacji } \\
\text { zdrowotnej }\end{array}$ & $\begin{array}{c}\text { Czas } \\
\text { trwania } \\
\text { badania }\end{array}$ & $\begin{array}{l}\text { Metody oceny } \\
\text { skuteczności } \\
\text { interwencji }\end{array}$ & Wyniki \\
\hline $\begin{array}{l}\text { Sadler i wsp. } \\
1998[16]\end{array}$ & $\begin{array}{l}\text { Program } \\
\text { prewencji } \\
\text { nowotworów } \\
\text { piersi }\end{array}$ & $\begin{array}{l}145 \text { klientek } \\
\text { powyżej } 34 \text { lat } \\
\text { (Afroamerykanki), } \\
\text { San Diego, Stany } \\
\text { Zjednoczone }\end{array}$ & $\begin{array}{l}\text { Nauka samobadania } \\
\text { piersi. } \\
\text { Badania } \\
\text { skriningowe. }\end{array}$ & $\begin{array}{l}\text { Edukacja klientek przez } \\
\text { przeszkolonych kosmetologów } \\
(\mathrm{n}=8) \text {. }\end{array}$ & $\begin{array}{l}\text { Brak } \\
\text { danych }\end{array}$ & $\begin{array}{l}\text { Ankieta wśród } \\
\text { klientów, badanie } \\
\text { telefoniczne } \\
4 \text { miesiące później. }\end{array}$ & $\begin{array}{l}\text { Po uzyskaniu informacji o podwyższonym ryzyku } \\
\text { zachorowania na raka piersi (wiek powyżej } 50 \text { r.ż. } \\
\text { jako czynnik ryzyka) klientki były bardziej skłonne do } \\
\text { samokontroli piersi, a klientki powyżej } 50 \text { roku życia do } \\
\text { wykonywania mammografii. } 100 \% \text { klientek akceptowało } \\
\text { i popierało pełnienie przez kosmetologów roli edukatora } \\
\text { zdrowotnego. }\end{array}$ \\
\hline $\begin{array}{l}\text { Linnan i wsp. } \\
2005[22]\end{array}$ & $\begin{array}{l}\text { Program } \\
\text { prewencji } \\
\text { nowotworów }\end{array}$ & $\begin{array}{l}56 \text { klientek, } \\
\text { Południowa } \\
\text { Karolina, } \\
\text { Stany Zjednoczone }\end{array}$ & $\begin{array}{l}\text { Zachęta do } \\
\text { konsumpcji warzyw } \\
\text { i owoców } 5 \text { razy } \\
\text { dziennie, codziennej } \\
30 \text {-minutowej } \\
\text { aktywności fizycznej } \\
\text { oraz korzystania } \\
\text { z infolinii } \\
\text { telefonicznej na } \\
\text { temat nowotworów. }\end{array}$ & $\begin{array}{l}\text { Edukacja klientek przez } \\
\text { przeszkolonych kosmetologów } \\
(\mathrm{n}=5) \text { w dwóch salonach } \\
\text { (przewaga klientów rasy czarnej } \\
\text { w jednym i rasy białej w drugim). } \\
\\
\text { Rozmowa edukacyjna z klientem. } \\
\text { Broszury informacyjne, plakaty. }\end{array}$ & 7 tygodni & $\begin{array}{l}\text { Ankieta (24 pytania) } \\
12 \text { miesięcy później. }\end{array}$ & $\begin{array}{l}55 \% \text { uczestniczek zgłosiło zmianę zachowan zdrowotnych, } \\
74,1 \% \text { skorzystało z infolinii telefonicznej, } 70,9 \% \\
\text { stosowało } 30 \text {-minutowe ćwiczenia fizyczne, } 70,9 \% \\
\text { spożywało } 5 \text { razy dziennie owoce i warzywa, } 45,1 \% \\
\text { utrzymywało prawidłową wagę, } 38,7 \% \text { stosowało dietę } \\
\text { ubogą w tłuszcze. } 53,8 \% \text { podczas wizyty u lekarza lepiej } \\
\text { rozumiała przekazywane informacje zdrowotne, } 54 \% \\
\text { zadawała pytania związane z nowotworami podczas wizyty } \\
\text { u lekarza. } 35,9 \% \text { skorzystała z wiadomości nabytych } \\
\text { w ramach programu podczas wizyty u lekarza. }\end{array}$ \\
\hline $\begin{array}{l}\text { Johnson } \\
\text { i wsp. } 2010 \\
\text { [23] }\end{array}$ & $\begin{array}{l}\text { Program } \\
\text { promocji } \\
\text { zdrowego } \\
\text { stylu życia }\end{array}$ & $\begin{array}{l}\text { Klientki rasy } \\
\text { czarnej w wieku } \\
18-70 \text { r.ż. }(10 \\
\text { osobowa grupa } \\
\text { badana, } 10 \text { osobowa } \\
\text { grupa kontrolna), } \\
\text { Południowa } \\
\text { Karolina, Stany } \\
\text { Zjednoczone }\end{array}$ & $\begin{array}{l}\text { Zachęta do spożycia } \\
\text { warzyw i owoców } \\
5 \text { razy dziennie, } \\
\text { stosowania } \\
\text { codziennej } \\
\text { 30-minutowej } \\
\text { aktywności fizycznej } \\
\text { oraz picia wody. }\end{array}$ & $\begin{array}{l}\text { Edukacja klientek przez } \\
\text { kosmetologów przeszkolonych } \\
\text { pod kątem motywacji do } \\
\text { utrzymywania odpowiednich } \\
\text { zachowań prozdrowotnych. } \\
\text { Rozmowa z klientem, materiały } \\
\text { informacyjne. Grupa kontrolna } \\
\text { otrzymywała jedynie materiały } \\
\text { informacyjne, bez rozmowy } \\
\text { motywacyjnej. }\end{array}$ & 6 tygodni & $\begin{array}{l}\text { Ankieta (tydzień } \\
\text { przed rozpoczęciem } \\
\text { i tydzień przed } \\
\text { zakończeniem } \\
\text { programu). }\end{array}$ & $\begin{array}{l}\text { Znaczaco wzrosła konsumpcja owoców i warzyw w grupie } \\
\text { badanej (średnio z } 1,8 \text { do } 3,4 \text { porcji dziennie), } \\
\text { a zmalała w grupie kontrolnej (z } 3,8 \text { do } 3,5 \text { porcji } \\
\text { dziennie). W obu grupach nieznacznie wzrósł czas } \\
\text { aktywności fizycznej (średnio z 29,0 do } 32,5 \text { minut } \\
\text { dziennie w grupie badanej i z 24,9 do } 33,5 \text { w grupie } \\
\text { kontrolnej). Wzrosło nieznacznie spożycie wody w obu } \\
\text { grupach (średnio z 4,9 do } 6,8 \text { szklanek wody w grupie } \\
\text { badanej i z 4,0 do 4,6 szklanek wody w grupie kontrolnej - } \\
\text { różnice nieistotne statystycznie). }\end{array}$ \\
\hline $\begin{array}{l}\text { Kleindorfer } \\
\text { i wsp. } 2008 \\
\text { [24] }\end{array}$ & $\begin{array}{l}\text { Program } \\
\text { edukacji } \\
\text { zdrowotnej } \\
\text { na temat } \\
\text { udaru }\end{array}$ & $\begin{array}{l}383 \text { klientki rasy } \\
\text { czarnej, Stany } \\
\text { Zjednoczone }\end{array}$ & $\begin{array}{l}\text { Objawy i czynniki } \\
\text { ryzyka udaru } \\
\text { mózgu. }\end{array}$ & $\begin{array}{l}\text { Edukacja klientek podczas wizyty } \\
\text { w salonie przez przeszkolonych } \\
\text { kosmetologów ( } \mathrm{n}=30 \text { ). } \\
\text { Rozmowa edukacyjna, broszury } \\
\text { edukacyjne. }\end{array}$ & $\begin{array}{l}\text { Brak } \\
\text { danych }\end{array}$ & $\begin{array}{l}\text { Ankieta przed } \\
\text { rozpoczęciem } \\
\text { edukacji ( } 383 \\
\text { respondentki). } \\
\text { Ankieta } 6 \text { tygodni } \\
\text { po zakończeniu } \\
\text { programu ( } 354 \\
\text { respondentki). } \\
\text { Ankieta } 5 \text { miesięcy } \\
\text { po zakończeniu } \\
\text { programu (318 } \\
\text { respondentek). }\end{array}$ & $\begin{array}{l}\text { 40,7\% klientek potrafiło wymienić przynajmniej } 3 \text { objawy } \\
\text { udaru, } 46,7 \% \text { znało przynajmniej } 3 \text { czynniki ryzyka udaru. } \\
50,8 \% \text { klientek potrafiło wymienić przynajmniej } 3 \text { objawy } \\
\text { udaru, } 54,0 \% \text { znało przynajmniej } 3 \text { czynniki ryzyka udaru. } \\
50,6 \% \text { klientek potrafiło wymienić przynajmniej } 3 \text { objawy } \\
\text { udaru, } 48,7 \% \text { znało przynajmniej } 3 \text { czynniki ryzyka udaru. }\end{array}$ \\
\hline
\end{tabular}

towanie kosmetologa do roli edukatora zdrowotnego, lecz także z uwagi na możliwość dotarcia do szerokiego grona osób. Z tego względu w programie zdrowotnym skierowanym do młodzieży w Liberii salony kosmetologiczne zostały wykorzystane obok kościołów, sklepów muzycznych, fotograficznych i kantorów jako jedno z miejsc dystrybucji prezerwatyw [25]. Podobnie w Stanach Zjednoczonych [26] program prewencji nadciśnienia realizowany był przez wolontariuszy w gabinetach kosmetologicznych, a ponadto w kościołach, salonach fryzjerskich czy remizach strażackich. Gesler wskazał również na salony kosmetyczne jako miejsce odpowiednie dla propagowania informacji o cukrzycy [27]. Sharps i wsp. [28] wykorzystali salony kosmetyczne jako miejsce zwiększania świadomości na temat menopauzy. O efektywności salonów kosmetologicznych w prewencji chorób i promocji zdrowia wśród Afroamerykanów przekonują Linnan i Ferguson [29]. Według Polanda działania edukacyjne prowadzone w miejscu, w którym ludzie pracują, uczą się i spędzają wolny czas przynosi efekty lepsze od tradycyjnych sposobów realizacji promocji zdrowia [30].

\section{Wnioski}

1. Kosmetolog, obok pielęgnacji i upiększania ciała ludzkiego, jest powołany do pełnienia roli edukatora zdrowotnego.

2. Dotychczasowe doświadczenia przekonują, że realizowane przez kosmetologów programy edukacyjne są efektywne i korzystne dla zdrowia publicznego.

3. Rola kosmetologa jako edukatora zdrowotnego może odbywać się spontanicznie w oparciu o wykształcenie nabyte $\mathrm{w}$ trakcie nauki zawodu lub wiązać się z realizacją programów zdrowotnych na zlecenie organizacji i stowarzyszeń.

4. Salony kosmetologiczne są doskonałym miejscem do szerzenia edukacji zdrowotnej i promocji zdrowia ze względu na możliwość dotarcia do szerokiego grona odbiorców, postrzeganie salonu jako przyjaznego miejsca relaksu oraz naturalnie pojawiające się okazje do rozmowy na tematy zdrowotne.

5. Sytuacja w salonie kosmetologicznym stwarza warunki do nawiązywania relacji zaufania i budowania więzi pomiędzy klientem i kosmetologiem, a przez to sprzyja otwartości i gotowości do rozmowy o problemach zdrowotnych. 


\section{Acknowledgment}

The authors express their gratitude to Professor Laura Linnan and Dr Georgia Sadler for providing their articles and valuable suggestions.

\section{Piśmiennictwo}

1. Ottawa Charter for Health Promotion First International Conference on Health Promotion Ottawa, 21 November 1986 - WHO/HPR/HEP/95.1. URL: http://www.who. int/hpr/NPH/docs/ottawa_charter_hp.pdf (dokument elektroniczny, stan na dzień 11.03.2012)

2. World Health Organization: Health Education. URL: http://www.who.int/topics/health education/en/ (dokument elektroniczny, stan na dzień 10.03.2012)

3. Jones DK: Promoting cancer prevention through beauty salons and barbershops. N C Med J 2008; 69(4): 339-40.

4. Kuźmicz I, Masłowska J, Wasilewska I, Kleszczewska E: Znaczenie pracy kosmetologa w profilaktyce nowotworów piersi. Pol J Cosmetol 2009; 12(3): 190-3.

5. Wurzbach M.E: Developing successful programs. W: Community health education and promotion: A guide to program design and Evaluation. Jones and Bartlett Publishers, Sudbury 2004: 422-3.

6. Ministerstwo Nauki i Szkolnictwa Wyższego: Standardy kształcenia na kierunku Kosmetologia. 2007. URL:http:// www.bip.nauka.gov.pl/_gAllery/63/88/6388/Zalacznik nr_4-kosmetologia.pdf (dokument elektroniczny, stan na dzień 25.03.2012)

7. Linnan LA: Beauty and the beast: results of the Rhode Island smokefree shop initiative. Am J Public Health 2002; 92(1): 27-8.

8. Browne RC: Most Black women have a regular source of hair care but not medical care. J Natl Med Assoc 2006; 98(10): 1652-3.

9. Wilson TE, Fraser-White M, Feldman J, Homel P, Wright S, King G, Coll B, Banks S, Davis-King D, Price M, Browne R: Hair salon stylists as breast cancer prevention lay health advisors for African American and AfroCaribbean women. J Health Care Poor Underserved 2008; 19(1): 216-26.

10. Makowska B, Frączek B: Cosmetologists preparation in the field of health promotion and health education. Rocz Panstw Zakl Hig 2006; (Suppl 57): 89-93.

11. Antoszewski B, Kasielska A, Jokiel I, Fijałkowska M: Zmiany skórne - prewencyjna rola kosmetologa. Pol J Cosmetol 2010; 13(3): 171-6.

12. Dana A, Makowiec-Dąbrowska T: Rola kosmetologa w profilaktyce i wczesnym wykrywaniu nowotworów złośliwych skóry. Pol J Cosmetol 2010; 13(3): 148-60.

13. Linnan LA, Kim AE, Wasilewski Y, Lee AM, Yang J, Solomon F: Working with licensed cosmetologists to promote health: results from the North Carolina BEAUTY and Health Pilot Study. Prev Med 2001; 33(6): 606-12.

14. Solomon FM, Linnan LA, Wasilewski Y, Lee AM, Katz ML, Yang J: Observational study in ten beauty salons: results informing development of the North Carolina BEAUTY and Health Project. Health Educ Behav 2004; 31(6): 790-807.

15. Lieberman A, Harris D: Acknowledging adult bias: a focus-group approach to utilizing beauty salons as health-education portals for inner-city adolescent girls. Health Promot Pract 2007; 8(2): 205-13.

16. Sadler GR, Thomas AG, Dhanjal SK, Gebrekristos B, Wright FA: Breast cancer screening adherence in African-American women. Black cosmetologists promoting health. Cancer 1998; 83(Suppl 8): 1836-9.

17. Sadler GR, Meyer MW, Ko CM, Butcher C, Lee S, Neal T, Reed L, Veals AE, Gilpin EA: Black cosmetologists promote diabetes awareness and screening among African American women. Diabetes Educ 2004; 30(4): 676-85.

18. Brown N, Naman P, Homel P, Fraser-White M, Clare R, Browne R: Assessment of preventive health knowledge and behaviors of African-American and Afro-Caribbean women in urban settings. J Natl Med Assoc 2006; 98(10): 1644-51.

19. Sadler GR, Ko CM, Cohn JA, White M, Weldon RN, Wu P: Breast cancer knowledge, attitudes, and screening behaviors among African American women: the Black cosmetologists promoting health program. BMC Public Health 2007; 17(7): 57.

20. Collins BS, Hollander RB, Koffman DM, Reeve R, Seidler $\mathrm{S}$ : Women, work and health: issues and implications for worksite health promotion. Women Health 1997; 25(4): 3-38.

21. Forte DA: Community-based breast cancer intervention program for older African American women in beauty salons. Public Health Rep 1995; 110(2): 179-83.

22. Linnan LA, Ferguson YO, Wasilewski Y, Lee AM, Yang J, Solomon F, Katz M: Using community-based participatory research methods to reach women with health messages: results from the North Carolina BEAUTY and Health Pilot Project. Health Promot Pract 2005; 6(2): 164-73.

23. Johnson LT, Ralston PA, Jones E: Beauty salon health intervention increases fruit and vegetable consumption in African-American women. J Am Diet Assoc 2010; 110(6): 941-5.

24. Kleindorfer D, Miller R, Sailor-Smith S, Moomaw CJ, Khoury J, Frankel M: The challenges of communitybased research: the beauty shop stroke education project. Stroke 2008; 39(8): 2331-5.

25. Harris AO, Jubwe S, Kennedy SB, Taylor CH, Martin RB, Bee EM, Perry OS, Massaquoi MT, Woods DV, Barbu EM: Condom social marketing program to prevent HIV/ AIDS in post-conflict Liberia. Afr Health Sci 2011; 11(Suppl 1): 77-81.

26. Kong BW: Community-based hypertension control programs that work. J Health Care Poor Underserved 1997; 8(4): 409-15.

27. Gesler WM, Arcury TA, Skelly AH, Nash S, Soward A, Dougherty M: Identifying diabetes knowledge network nodes as sites for a diabetes prevention program. Health Place 2006; 12(4): 449-64.

28. Sharps P.W, Phillips J, Oguntimalide L, Saling J, Yun S: Knowledge, attitudes, perceptions and practices of African-American women toward menopausal health. J Nat Black Nurses Assoc 2003; 14(2): 9-15.

29. Linnan LA, Ferguson YO: Beauty salons: a promising health promotion setting for reaching and promoting health among African American women. Health Educ Behav 2007; 34(3): 517-30.

30. Poland B, Krupa G, McCall D: Settings for health 
promotion: an analytic framework to guide intervention design and implementation. Health Promot Pract 2009; 10(4): 505-16.

\section{Finansowanie i konflikt interesów}

Przedstawione badania i przygotowanie niniejszej publikacji zostało w całości sfinansowane z własnych środków autorów. Autorzy deklarują niewystępowanie konfliktu interesów w odniesieniu do treści zawartych w niniejszej pracy.

\section{Adres do korespondencji}

mgr Danuta Plichta

Zakład Dermatologii Doświadczalnej i Kosmetologii

Wydział Farmaceutyczny UJ

ul. Medyczna 9, 30-688 Kraków

Tel.: 1262058 30, Fax: 126205645

E-mail: danuta.plichta@uj.edu.pl

Data złożenia: 12.05.2012

Data akceptacji: 13.06 .2012

Data aktualizacji: 30.11 .2012

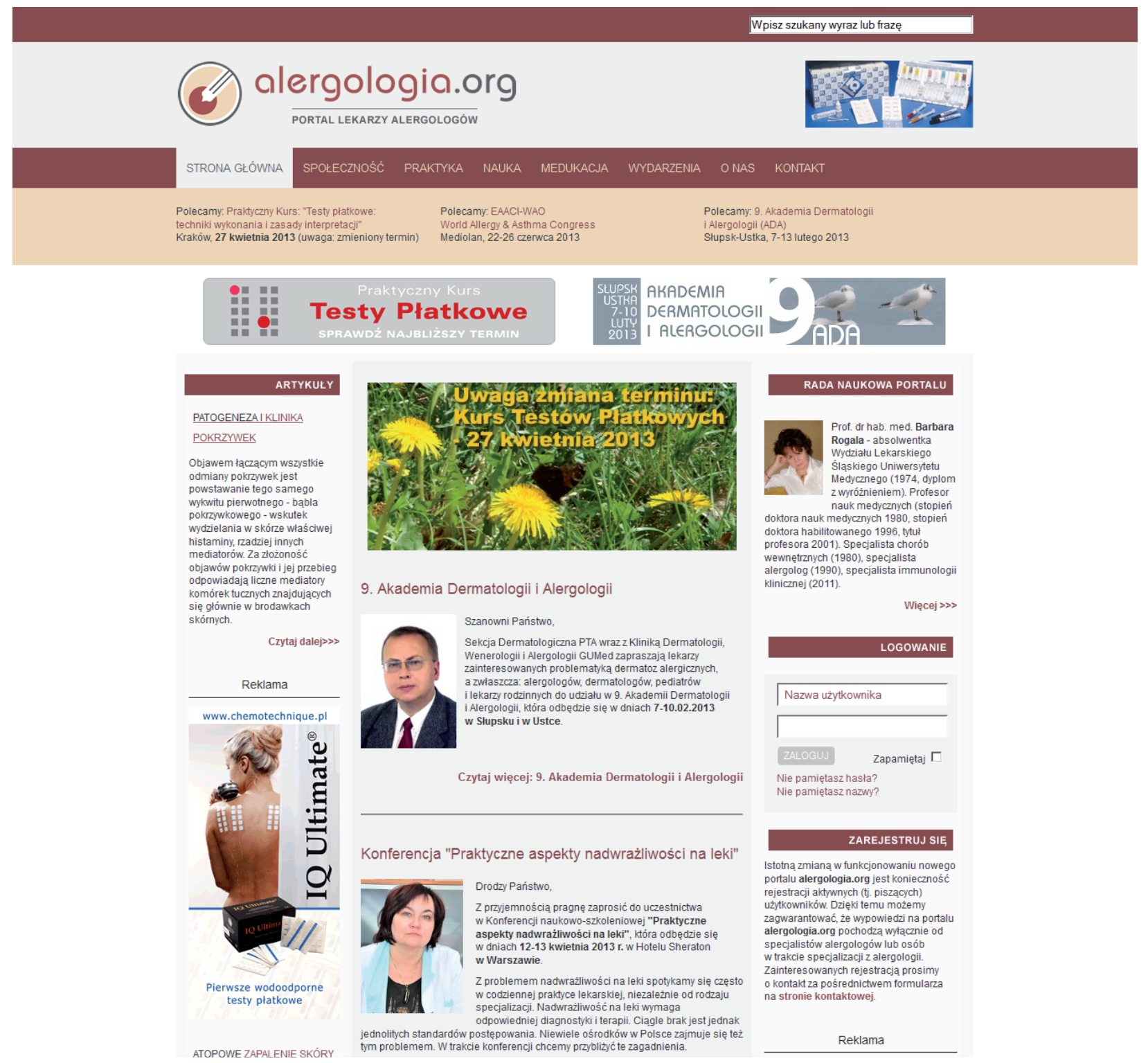

